\title{
Two faces of lupus nephritis? Questions
}

\section{Şeyda Doğantan ${ }^{1}$ - Neslihan Günay ${ }^{2}$ (1) - Sema Nur Taşkın ${ }^{1}$ (D) - Aynur Gencer Balaban ${ }^{2}$ (D) • Ayşenur Paç Kısaarslan ${ }^{1}$ (D) • Sibel Yel $^{2}$ (D) - Hülya Akgün ${ }^{3}$ (ID $\cdot$ İsmail Dursun ${ }^{2}$ (D) $\cdot$ Muammer Hakan Poyrazoğlu ${ }^{1,2}$ (D)}

Received: 31 December 2020 / Accepted: 19 January 2021 / Published online: 26 March 2021

(C) The Author(s) 2021

Keywords Child $\cdot$ Hemolytic anemia $\cdot$ Polyarthralgia $\cdot$ Proteinuria $\cdot$ Glomerulonephritis $\cdot$ Systemic lupus erythematosus

\section{Case}

An 11-year-old girl was admitted with hemolytic anemia and polyarthralgia that had persisted for 6 months. Her family history was remarkable for Sjogren's syndrome. On admission, she had a pallor appearance and arthralgia on the ankles and knees.

Laboratory findings were as follows: hemoglobin $4.7 \mathrm{~g} / \mathrm{dL}$, white blood cell count $8000 / \mathrm{mm}^{3}$, platelets $210.000 / \mathrm{mm}^{3}$, reticulocyte ratio $7.9 \%$, BUN $16 \mathrm{mg} / \mathrm{dL}$, creatinine $0.41 \mathrm{mg} / \mathrm{dl}$, LDH 576 U/L, ANA 1:1000, anti-ds-DNA negative, ACA positive, anti-beta 2 glycoprotein antibody positive, serum $\mathrm{C} 3$ and 4 normal, direct globulin positive, lupus anticoagulant ratio 1.27 (1+), p-ANCA and c-ANCA negative. A 24-h urine collection showed nephrotic range proteinuria of $1632 \mathrm{mg} / \mathrm{m}^{2} /$ day.

Kidney ultrasound revealed increased renal parenchymal echogenicity. Kidney biopsy was performed and demonstrated mild mesangial cell proliferation without any immunofluorescence staining for IgG, IgM, IgA, C3, C1q, kappa, or lambda light chains (Fig. 1a, b).

Based on the clinical and laboratory findings, she was diagnosed with systemic lupus erythematosus (SLE) and treated with steroids, mycophenolate mofetil (MMF), and hydroxychloroquine since kidney biopsy was compatible with mesangial proliferative glomerulonephritis.

\section{Questions}

1. What is your diagnosis based on the renal histopathologic findings?

2. What is the best tool for diagnosis?

3. What is the possible underlying mechanism of kidney involvement?

4. What are the treatment options for the patient?

The answers to these questions can be found at https://doi.org/10.1007/ s00467-021-04962-8.

Şeyda Doğantan

drseydacayan@gmail.com

Neslihan Günay

neslihankosr@hotmail.com

Sema Nur Tașkın

sntistanbul@gmail.com

Aynur Gencer Balaban

aynurgecerbalaban@mail.com

Ayșenur Paç Kısaarslan

aysenurkisaarslan@hotmail.com

Sibel Yel

drsibelyel@gmail.com
Hülya Akgün

hakgun@erciyes.edu.tr

İsmail Dursun

drdursun@hotmail.com

Muammer Hakan Poyrazoğlu

drpoyrazoglu@yahoo.com

Department of Pediatric Rheumatology, Erciyes University Medical Faculty, Kayseri, Turkey

2 Department of Pediatric Nephrology, Erciyes University Medical Faculty, Kayseri, Turkey

3 Pathology Department, Erciyes University Medical Faculty, Kayseri, Turkey 
Fig. 1 Pathological findings from kidney biopsy. Light microscopy revealed mild mesangial cell proliferation (a hematoxylin eosin, $\times 100$ and $\mathbf{b}$ hematoxylin eosin, $\times 400$ )
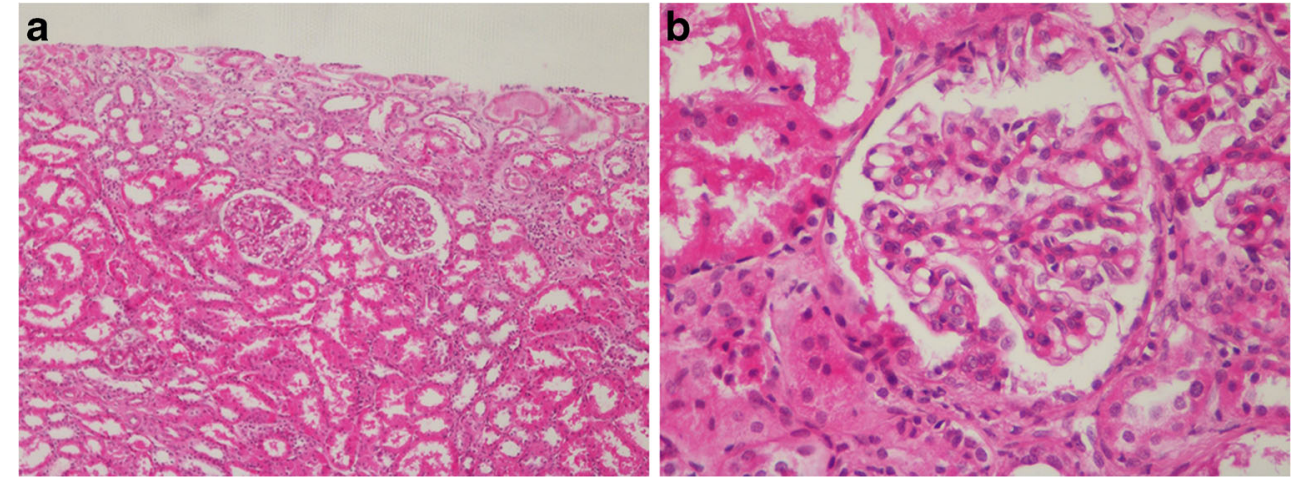

\section{Declarations}

Conflict of interest The authors declare no competing interest.

Open Access This article is licensed under a Creative Commons Attribution 4.0 International License, which permits use, sharing, adaptation, distribution and reproduction in any medium or format, as long as you give appropriate credit to the original author(s) and the source, provide a link to the Creative Commons licence, and indicate if changes were made. The images or other third party material in this article are included in the article's Creative Commons licence, unless indicated otherwise in a credit line to the material. If material is not included in the article's Creative Commons licence and your intended use is not permitted by statutory regulation or exceeds the permitted use, you will need to obtain permission directly from the copyright holder. To view a copy of this licence, visit http://creativecommons.org/licenses/by/4.0/.

Publisher's note Springer Nature remains neutral with regard to jurisdictional claims in published maps and institutional affiliations. 